\title{
Correlation between survival in water and persistence of infectivity in soil of Heterorhabditis spp. isolates
}

\author{
Birgit HASS *, Martin J. Downes and Christine T. GRIFFIN ** \\ Institute of Bioengineering and Agroecology, and Department of Biology, National University of Ireland, Maynooth, \\ Co. Kildare, Ireland
}

Received: 20 November 2000; revised: 19 June 2001 Accepted for publication: 19 June 2001

\begin{abstract}
Summary - Persistence in soil of ten isolates of three species of Heterorhabditis was monitored by baiting the soil with insects and recording their mortality. Infective juveniles (IJ) of the same ten isolates were also incubated in tap water and their survival recorded. Both tests were conducted in the laboratory at $20^{\circ} \mathrm{C}$. Inter- and intraspecific differences in persistence were detected: H. bacteriophora HI was the most persistent isolate in both media. There was no clear division between H. megidis (North West European Group) and $H$. downesi, but isolates of $H$. downesi tended to be less persistent than those of $H$. megidis. Nematodes persisted longer in soil than in water: after 180 days in water, all IJ were dead in seven of the ten isolates, whereas all isolates still killed insects after 265 days in soil. Persistence of isolates in soil (indicated by $\mathrm{LT}_{50}$, the time that nematode-infested soil retained the ability to kill $50 \%$ of the bait insects) was correlated with their survival in water (represented by $\mathrm{ST}_{50}$, the time at which $50 \%$ of the IJ were still alive), with $r^{2}=0.84$, indicating that similar factors were responsible for the reduction in each parameter.
\end{abstract}

Keywords - entomopathogenic nematode, H. bacteriophora, H. downesi, H. megidis, interspecific variation, intraspecific variation.

The survival of entomopathogenic nematode infective juveniles (IJ) varies greatly depending on the species (Molyneux, 1985; Lewis et al., 1995; Patel et al., 1997) and there is also evidence for intraspecific differences (Curran, 1993; Fitters, 1999). Mortality in soil may be either a result of directly lethal factors, such as predation or desiccation, or due to starvation. Indirect evidence for lethal effects of nematode antagonists is seen in the fact that IJ survive longer in sterilised or pasteurised than in unsterilised media (Ishibashi \& Kondo, 1986a, b, 1987; Timper et al., 1991). Interspecific differences in susceptibility to fungal pathogens (Timper et al., 1991) and other antagonists may contribute to differences in soil persistence. It is generally assumed that interspecific differences in survival in soil under laboratory conditions are related to different rates of lipid utilisation(Molyneux, 1985; Kung et al., 1991) but this has rarely been explicitly tested.

When stored in water, IJ gradually deplete their lipid reserves (Vänninen, 1990; Lewis et al., 1995; Fitters \& Griffin, 1996; Patel et al., 1997) and starvation is probably the main cause of their mortality (Fitters, 1999; Qiu \& Bedding, 2000). If starvation were also the major cause of mortality in soil, then correlation between rates of survival in soil and in water would be expected. The aim of the present study was to ascertain whether survival of IJ in water is a good predictor of their persistence in soil, which would indicate the importance of factors such as rate of utilisation of reserves in determining inter- and intraspecific differences in persistence.

We used ten isolates of Heterorhabditis belonging to three species, and recorded persistence in dry, unsterilised soil and in tap water. The rank orders of survival of isolates in the two media were compared. Persistence in soil was not measured directly by extracting the nematodes. Instead, the soil was baited with insects and the resulting bait insect mortality indicated the presence of infective nematodes. Hass (1996) showed that extraction of IJ and soil baiting allow a similar ranking of Heterorhabditis spp. isolates in terms of persistence in soil. Although infectivity may decline faster than survival (e.g., Vänninen, 1990; Hass et al., 1999), survival cannot decline faster

\footnotetext{
* Present address: Institute of Phytopathology, Department of Biotechnology and Biological Control, Christian-Albrechts-University Kiel, 24223 Raisdorf, Germany.

** Corresponding author, e-mail: Christine.Griffin@may.ie
} 
than infectivity, and thus soil baiting as a method of detecting entomopathogenic nematodes may underestimate, but not overestimate, their survival.

\section{Materials and methods}

\section{NEMATODES}

Ten isolates of Heterorhabditis of three species, H. bacteriophora, the North West European (NWE) type of $H$. megidis and $H$. downesi (formerly known as Heterorhabditis sp., Irish type) were used. The source and origin of the isolates are shown in Table 1. They were cultured in late instar larvae of Tenebrio molitor. Harvested IJ were washed three times by sedimentation in tap water, and were stored in tap water at $9^{\circ} \mathrm{C}$ for 10 days before use.

Table 1. Source and origin of the Heterorhabditis isolates used in the experiment.

\begin{tabular}{|c|c|c|c|}
\hline Species & Isolate & Origin & Source \\
\hline H. bacteriophora & $\mathrm{HI}$ & Italy & $\begin{array}{l}\text { P.R. Westerman/ } \\
\text { W.R. Simons, from } \\
\text { K.V. Deseö, Italy }\end{array}$ \\
\hline \multirow[t]{4}{*}{$\begin{array}{l}\text { H. megidis } \\
\text { (NWE Group) }\end{array}$} & UK211 & $\begin{array}{l}\text { South coast of } \\
\text { England, UK }\end{array}$ & W.M. Hominick \\
\hline & HF85 & $\begin{array}{l}\text { Flevoland, The } \\
\text { Netherlands }\end{array}$ & $\begin{array}{l}\text { P.R. Westerman/ } \\
\text { W.R. Simons }\end{array}$ \\
\hline & HB1 & $\begin{array}{l}\text { Brabant, The } \\
\text { Netherlands }\end{array}$ & $\begin{array}{l}\text { P.R. Westerman/ } \\
\text { W.R. Simons }\end{array}$ \\
\hline & HSH1 & $\begin{array}{l}\text { Schleswig- } \\
\text { Holstein, } \\
\text { Germany }\end{array}$ & R.-U. Ehlers \\
\hline \multirow[t]{5}{*}{ H. downesi } & S29 & $\begin{array}{l}\text { Sutherland, } \\
\text { Scotland, UK }\end{array}$ & Own collections \\
\hline & K122 & $\begin{array}{l}\text { Curracloe, } \\
\text { Co. Wexford, } \\
\text { Ireland }\end{array}$ & Own collections \\
\hline & M208 & $\begin{array}{l}\text { Inchydonny, } \\
\text { Co. Cork, } \\
\text { Ireland }\end{array}$ & Own collections \\
\hline & M245 & $\begin{array}{l}\text { Magilligan, } \\
\text { Co. Derry, } \\
\text { Ireland }\end{array}$ & Own collections \\
\hline & M266 & $\begin{array}{l}\text { White Strand, } \\
\text { Co. Donegal, } \\
\text { Ireland }\end{array}$ & Own collections \\
\hline
\end{tabular}

SOIL

The soil used in this experiment came from a garden on the National University of Ireland, Maynooth campus and had $22.5 \%$ organic matter and 33, 48 and $19 \%$ by weight of sand, silt and clay, respectively (assessed by the Teagasc Soil Laboratory, Johnstown Castle, Ireland). The soil was air dried on the laboratory bench. After inoculation with nematodes, soil moisture was $17 \%$ by weight (pF 3.8).

\section{PERSISTENCE OF INFECTIVITY IN SOIL}

Plastic beakers (250 ml with snap-on lid; Wilscanco Plastics Ltd, Dungannon, Co. Tyrone, Ireland) containing $120 \mathrm{~g}$ soil were each inoculated with $16000 \mathrm{IJ}$, applied in $2 \mathrm{ml}$ of tap water. Controls received tap water alone. Beakers, arranged in randomised complete blocks, were incubated in the dark at $20^{\circ} \mathrm{C}$. They were surrounded by a row of beakers containing the same soil as the experimental beakers to act as a buffer. Soil moisture was corrected weekly by adding water to each experimental beaker, as necessary, to maintain a previously determined weight. At intervals over a period of 313 days, three blocks were randomly chosen and the infectivity of the soil was tested by baiting with T. molitor larvae. Prior to baiting, the soil moisture content was adjusted to $22 \%$ ( $\mathrm{pF}$ 2.9) by mixing the nematode-inoculated soil with an equal amount of uninfested soil at $27 \%$ water content. The adjusted soil was then divided in two, and half was baited with 40 T. molitor larvae. This divison of the soil was done to maintain consistency with other, similar, experiments (Hass, 1996; Hass et al., 1999). The insects were gently mixed into the soil and incubated for 4 days at $20^{\circ} \mathrm{C}$ in the dark. Numbers of insects dead, alive and parasitised (as evidenced by characteristic colour) were recorded 3 days after removal from the soil.

\section{SURVIVAL IN TAP WATER}

In parallel with the above, survival of IJ in tap water was monitored over a 180 day period. For this, $9 \mathrm{~cm}$ diam. Petri dishes (replications), each containing 16000 $\mathrm{IJ}$ in $25 \mathrm{ml}$ of tap water, were incubated at $20^{\circ} \mathrm{C}$ in the dark in a randomised complete block design. At intervals during incubation, three blocks were randomly chosen and numbers of nematodes, dead and alive, were estimated from six replicate aliquots, with a minimum of $100 \mathrm{IJ}$ in each aliquot. Live nematodes were distinguished from dead on the basis of spontaneous movement, posture 
(not straight) and general appearance. Each block was assessed on only one occasion.

\section{STATISTICAL ANALYSIS}

Probit analysis (Version 5, SAS Institute, Cary, NC, USA) was used to calculate $\mathrm{ST}_{50}$ and $\mathrm{LT}_{50}$ values for survival in water and persistence of infectivity in soil, respectively. $\mathrm{ST}_{50}$ is the time at which $50 \%$ of the nematodes were still alive. $\mathrm{LT}_{50}$ is the time that nematode-infested soil retained the ability to kill $50 \%$ of the bait insects. $\mathrm{LT}_{50}$ values were calculated using only the data for the first 193 days, in order to be more comparable with the 180 day interval that was used for $\mathrm{ST}_{50}$ estimation. A correction for natural mortality (Abbott, 1925) was included.

\section{Results}

\section{SURVIVAL IN WATER}

There was a steady decline in the numbers of IJ alive in tapwater, beginning for most isolates within the first week of storage (Fig. 1). For seven of the ten isolates, all of the IJ were dead by day 147 . The remaining three isolates still had some IJ surviving on day 180 , the last assessment date: $18.4 \%$ of $H$. bacteriophora $\mathrm{HI}$, and $2-3 \%$ of both $H$. downesi $\mathrm{S} 29$ and $H$. megidis $\mathrm{UK} 211$ remained alive at that time. The time at which only $50 \%$ of the IJ in water were alive $\left(\mathrm{ST}_{50}\right)$ is given in Table 2 . HI had the highest $\mathrm{ST}_{50}$; at 98.8 days this was at least 46 days longer than any other isolate and differed significantly from all other isolates based on the non-overlap of fiducial limits (Table 2). Although $H$. megidis HB1 was not one of the three isolates surviving to day 147 , it had the second highest ranking $\mathrm{ST}_{50}$ (Table 2): this reflects the fact that $\mathrm{HB} 1 \mathrm{did}$ not show the same initial decline in numbers as most of the other isolates; $97 \%$ remained alive on day 21 (Fig. 1).

\section{PERSISTENCE OF INFECTIVITY IN SOIL}

For most isolates, soil infested with IJ continued to kill insects long after the IJ in water were all dead (Fig. 1). In soil, all ten isolates caused bait insect mortality on day 265 and five isolates (HI, M266, S29, HB1 and HSH1) still caused bait insect mortality on day 313 , the last assessment. Although insect mortality on day 0 ranged from $54.2-82.5 \%$, differences between the ten isolates were not significant (Kruskal Wallis, $H=16.09, P=$ $0.065)$. From day 0 to 7 , infectivity of the soil increased for all isolates, and the increase was significant for seven
Table 2. Fifty percent survival time ( $\left.S T_{50}\right)$ in tap water at $20^{\circ} \mathrm{C}$ of infective juveniles of ten Heterorhabditis isolates, ranked according to their survival time, from 1 (shortest) to 10 (longest).

\begin{tabular}{llrcc}
\hline Isolate & Species & Rank & $\begin{array}{c}\mathrm{ST}_{50} \\
\text { (days) }\end{array}$ & 95\% fiducial limits \\
\hline M208 & H. downesi & 1 & 24.7 & $18.1-31.1$ \\
M266 & H. downesi & 2 & 26.9 & $20.4-33.2$ \\
M245 & H. downesi & 3 & 28.9 & $23.3-34.4$ \\
HF85 & H. megidis & 4 & 37.7 & $28.3-46.9$ \\
K122 & H. downesi & 5 & 42.8 & $34.6-50.8$ \\
HSH1 & H. megidis & 6 & 42.8 & $26.2-60.6$ \\
S29 & H. downesi & 7 & 46.4 & $35.2-58.3$ \\
UK211 & H. megidis & 8 & 47.2 & $33.5-62.1$ \\
HB1 & H. megidis & 9 & 52.8 & $47.0-58.5$ \\
HI & H. bacteriophora & 10 & 98.8 & $68.4-175.6$ \\
\hline
\end{tabular}

Table 3. Persistence in soil at $20^{\circ} \mathrm{C}$ of ten Heterorhabditis isolates expressed as the time at which $50 \%$ of the Tenebrio molitor larvae used to bait soil samples were parasitised $\left(L T_{50}\right)$. Isolates are ranked according to their persistence, from 1 (shortest) to 10 (longest).

\begin{tabular}{llrrc}
\hline Isolate & Species & Rank & $\begin{array}{c}\mathrm{LT}_{50} \\
\text { (days) }\end{array}$ & 95\% fiducial limits \\
\hline M245 & H. downesi & 1 & 47.5 & $30.0-57.8$ \\
HF85 & H. megidis & 2 & 57.1 & $45.6-69.6$ \\
M208 & H. downesi & 3 & 66.6 & $43.5-101.2$ \\
M266 & H. downesi & 4 & 68.1 & $49.3-92.9$ \\
K122 & H. downesi & 5 & 86.1 & $64.2-120.7$ \\
UK211 & H. megidis & 6 & 105.1 & $70.7-186.5$ \\
HB1 & H. megidis & 7 & 106.8 & $80.2-148.5$ \\
HSH1 & H. megidis & 8 & 127.1 & $88.8-210.3$ \\
S29 & H. downesi & 9 & 145.6 & $77.0-649.3$ \\
HI & H. bacteriophora & 10 & 226.8 & $130.4-808.9$ \\
\hline
\end{tabular}

of the ten isolates (Mann-Whitney U-test, $P \leqslant 0.05$ ) but not for three (M208, M245 and M266) of the four H. downesi isolates.

The persistence of infectivity was summarised as the time at which nematode-infested soil retained the ability to kill $50 \%$ of the bait insects, or $50 \%$ lethality time $\left(\mathrm{LT}_{50}\right) . \mathrm{LT}_{50}$ for the ten isolates ranged from 47.5 to 226.8 days (Table 3). H. bacteriophora $\mathrm{HI}$ had the highest $\mathrm{LT}_{50}$ but, because of large $95 \%$ fiducial limits, it did not differ significantly from the next four top-ranking isolates.

The ranking order of the isolates based on the $50 \%$ survival time in water $\left(\mathrm{ST}_{50}\right)$ was broadly similar to the ranking based on the $50 \%$ lethality time $\left(\mathrm{LT}_{50}\right)$, measuring persistence in soil (Tables 2, 3). In both cases, HI ranked highest, while the four lowest ranking iso- 


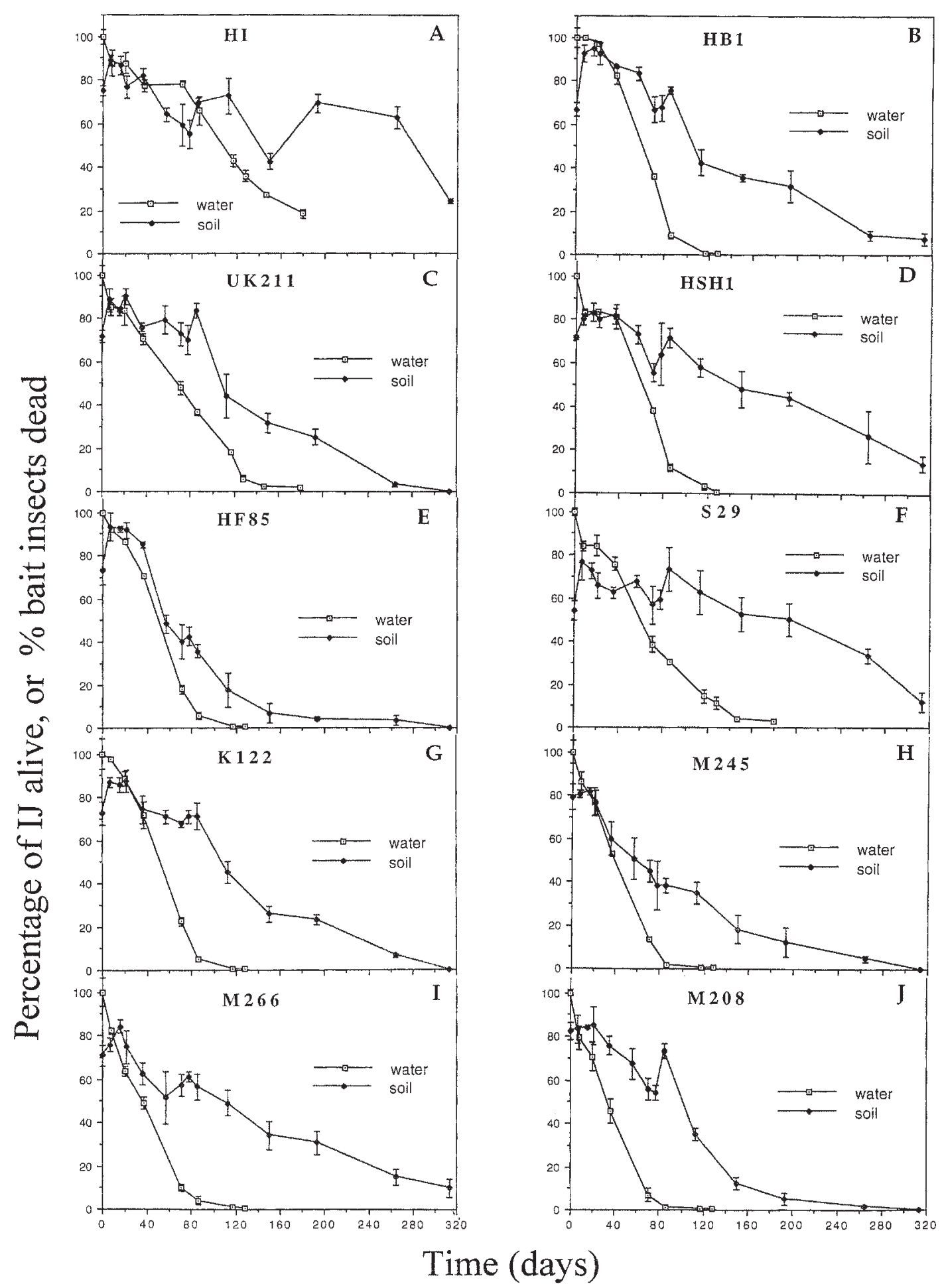

Fig. 1. Survival in water and persistence in soil of ten isolates of Heterorhabditis spp. at $20^{\circ} \mathrm{C}$. Survival was measured as percentage of infective juveniles (IJ) alive, and persistence in soil was determined as the percentage of bait insects (Tenebrio molitor larvae) killed during a 4-day exposure. Mean \pm SE. A: H. bacteriophora; B-E: H. megidis (North West European Group); F-J: H. downesi. 


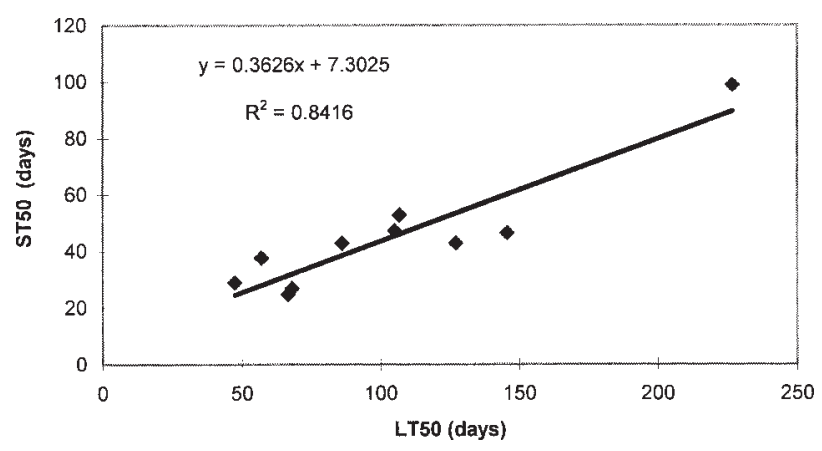

Fig. 2. Correlation between survival in water and persistence in soil for ten isolates of Heterorhabditis spp. at $20^{\circ} \mathrm{C}$. Survival is measured as the time at which 50\% of the infective juveniles remained alive $\left(S T_{50}\right)$, and persistence in soil as the time at which 50\% of the bait insects (Tenebrio molitor larvae) were killed $\left(L T_{50}\right)$, as determined by probit analysis.

lates were H. downesi isolates M208, M266 and M245, and $H$. megidis HF85. HF85 was the lowest ranking $H$. megidis isolate in both soil and water. There was no clear division between $H$. downesi and $H$. megidis: $\mathrm{K} 122$ and S29 ranked relatively highly on the basis of both $\mathrm{LT}_{50}$ and $\mathrm{ST}_{50}$ values compared to the other three $H$. downesi isolates tested, with significantly higher $\mathrm{ST}_{50}$ than those of the other members of the species. There was a significant $(P \leqslant 0.001)$ positive correlation between $\mathrm{ST}_{50}$ and $\mathrm{LT}_{50}$, with $r^{2}=0.84$ (Fig. 2).

\section{Discussion}

Mortality of nematodes in water at non-lethal temperatures and with adequate oxygen is assumed to be largely due to starvation: the depletion of stored energy reserves (Storey, 1984; Jung, 1991; Griffin et al., 1994; Fitters, 1999; Qiu \& Bedding, 2000). Although lipid levels were not quantified in the work reported here, the IJ stored in water became visibly lighter in appearance, becoming transparent before dying. Fitters and Griffin (1996) stored H. megidis under similar conditions and measured a gradual drop in reserves over 7 weeks at $20^{\circ} \mathrm{C}$, after which there was little further decline for most isolates, which had reached starvation level. The broadly similar ranking of the isolates by $\mathrm{ST}_{50}$ (survival in water) and $\mathrm{LT}_{50}$ (persistence of infectivity) in soil suggests that similar factors, such as starvation, are responsible for the decline in both media under the conditions tested. Hass et al. (unpubl.) showed that Heterorhabditis spp. isolates which utilised their reserves faster did not persist as long as those that utilised them at a slower rate, though the IJ apparently did not die of starvation. This suggests that either rates of lipid depletion directly affect mortality rates (e.g., by affecting tolerance to abiotic stress) or that a common factor links lipid utilisation and mortality, e.g., motility, which influences both the rate of lipid depletion and the extent of exposure to pathogens in the soil.

Heterorhabditis IJ of at least seven of the ten isolates tested survived longer in soil than in water. Similarly, long-term survival of the juveniles of Meloidogynejavanica and Tylenchulus semipenetrans was greater in soil than in water, and this was associated with a greater retention of body contents (Van Gundy et al., 1967) suggesting a slower utilisation of reserves. Although the soil used in the experiment reported here was quite dry, nematode movement should still have been possible. The soil had a $\mathrm{pF}$ of 3.8 which is below the permanent wilting point of plants (pF 4.2). Dispersal of juveniles of Ditylenchus dipsaci occurs, although it is restricted, at $\mathrm{pF} 3.87$ and it stops at $\mathrm{pF}$ 4.35 (Blake, 1961). Heterorhabditids and steinernematids are able to infect insect larvae at soil moisture below the permanent wilting point of plants (Molyneux \& Bedding, 1984; Koppenhöfer et al., 1995). Therefore it is likely that the Heterorhabditis spp. IJ were still able to move at the soil moisture level at which they were stored here (although this was not tested, as the soil moisture content was raised prior to baiting). Nevertheless, although capable of movement, the nematodes in soil may have been less active than those in water, or may have entered quiescence (Ishibashi \& Kondo, 1986b).

Three species of Heterorhabditis are known to occur in Europe: H. bacteriophora, H. megidis (NWE type) and the newly described H. downesi (Stock et al., 2001) which was previously known as the 'Irish type' of Heterorhabditis sp. (Smits et al., 1991; Griffin et al., 1999). Isolates of each of the three species were included in this study. The only $H$. bacteriophora isolate included (HI) survived longer than any other isolate both in water and in dry soil. These results are in accordance with findings of Griffin et al. (1994) that isolates of H. bacteriophora tended to survive better in distilled water than did isolates of $H$. downesi or the NWE group of $H$. megidis. No distinct line could be drawn between isolates of $H$. downesi and of $H$. megidis either in terms of IJ survival in water or the persistence of infectivity in soil. A trend was observed in that most of the $H$. downesi isolates lost their infectivity in soil quickly and also died more quickly in water. In general, isolates of $H$. megidis were intermediate in the ranking orders between $H$. downesi and $H$. bacteriophora. However, soil inoculated with $H$. megidis HF85 
lost the ability to kill Tenebrio more quickly than any other $H$. megidis isolate and even than $H$. downesi isolates. Griffin et al. (1994) also found that HF85 survived less well in distilled water than UK211 (the other H. megidis isolate included in that study). The observed overlap in performance of $H$. megidis and $H$. downesi may reflect the fact that those two species are closely related to one another (Smits et al., 1991; Joyce et al., 1994; Adams et al., 1998). However, it should also be noted that all of the isolates of these two species originated in the maritime fringe of North West Europe, while the only H. bacteriophora isolate included was from southern Europe (Italy); thus it is possible that the similarities between the isolates of the former two species reflect similar local ecological pressures experienced by the parental populations rather than being characteristic of either species as a whole.

It is clear that the pattern of infectivity of inoculated soil over time was not the same for all isolates. Thus, for example, the soil containing isolate $\mathrm{S} 29$ was less infective than soil containing HF85 on the earlier assessment dates, but retained the ability to kill a high proportion of bait insects for longer, reflected in an $\mathrm{LT}_{50}$ almost three times higher than that of HF85. Such differences may reflect evolutionary pressures associated with characteristic hosts of these isolates. Hosts that are available but difficult to infect may select for IJ of high early infectivity, such as shown by HF85, while hosts that are of erratic occurrence temporally may select for energy conservation rather than for high infectivity.

Soil infectivity increased for at least some members of all three species within the first week of storage. This confirms an increase observed for heterorhabditids in other, similar, experiments (Hass, 1996; Hass et al., 1999), and suggests that such increases are general, under some circumstances at least.

The soil used in the present work had been air dried on a laboratory bench to reduce the moisture content to a suitable level. Otherwise it was unmodified beyond the removal of larger stone fragments. Naturally occurring nematodes were not a confounding factor as Heterorhabditis has never been found in this soil (unpubl.). The soil used might therefore be said to be natural, but of course the conditions of the test (small containers without plants and held at a constant $20^{\circ} \mathrm{C}$ ) isolated it from many natural influences, such as those of plant roots and insect cadavers as well as many insect population fluctuations. Despite all these and other deviations from strictly natural soil conditions, the results of this experiment show that the relatively simple process of screening nematode isolates for survival in water could be used as a step in the selection of strains with good potential for persistence in soil.

\section{Acknowledgements}

This work was funded by the European Commission under ECLAIR AGRE 0002 and a Trainee Mobility Grant to B. Hass. We are grateful to Dr P.F.L. Fitters for his helpful comments on a draft of this paper, and to Dr L. Qiu and Dr R. Bedding for access to their paper prior to publication.

\section{References}

Аввотт, W.S. (1925). A method of computing the effectiveness of an insecticide. Journal of Economic Entomology 18, 265-367.

Adams, B.J., Burnell, A.M. \& Powers, T.O. (1998). A phylogenetic analysis of Heterorhabditis (Nemata: Rhabditidae) based on internal transcribed spacer 1 sequence data. Journal of Nematology 30, 22-39.

BLAKE, C.D. (1961). Importance of osmotic potential as a component of the total potential of the soil water on the movement of nematodes. Nature 192, 144-145.

Curran, J. (1993). Post-application biology of entomopathogenic nematodes in soil. In: Bedding, R.A., Akhurst, R.J. \& Kaya, H.K. (Eds). Nematodes and the biological control of insect pests. Melbourne, Australia, CSIRO, pp. 67-77.

FitTERS, P.F.L. (1999). Effect of long term storage on North West European Heterorhabditis sp. Ph.D. Thesis, National University of Ireland, Maynooth, 173 pp.

FitTERS, P.F.L. \& GRIFFIN, C.T. (1996). Starvation and persistence of Heterorhabditis sp. IOBC wprs Bulletin 19 (9), 112-114.

Griffin, C.T., Finnegan, M.M. \& Downes, M.J. (1994). Environmental tolerances and the dispersal of Heterorhabditis: survival and infectivity of European Heterorhabditis following prolonged immersion in seawater. Fundamental and Applied Nematology 17, 415-421.

Griffin, C.T., DiX, I., Joyce, S.A., Burnell, A.M. \& Downes, M.J. (1999). Isolation and characterisation of $\mathrm{He}$ terorhabditis spp. from Hungary, Estonia and Denmark. Nematology 1, 321-332.

HASs, B.K. (1996). Persistence of entomopathogenic nematodes of the genus Heterorhabditis Poinar 1975 with emphasis on effects of natural ageing under starvation. Ph.D. Thesis, National University of Ireland, Maynooth, 179 pp.

Hass, B., Griffin, C.T. \& Downes, M.J. (1999). Persistence of Heterorhabditis infective juvenile populations in moist soil: comparison of extraction and infectivity measurements. Journal of Nematology 31, 508-516. 
Ishibashi, N. \& Kondo, E. (1986a). Steinernema feltiae (DD-136) and Steinernema glaseri: persistence in soil and bark compost and their influence on native nematodes. Journal of Nematology 18, 310-316.

IshibASHi, N. \& Kondo, E. (1986b). A possible quiescence of the applied entomogenous nematode, Steinernema feltiae, in soil. Japanese Journal of Nematology 16, 66-67.

IshibASHi, N. \& Kondo, E. (1987). Dynamics of the entomogenous nematode Steinernema feltiae applied to soil with and without nematicide treatment. Journal of Nematology 19, 404-412.

Joyce, S.A., Griffin, C.T. \& Burnell, A.M. (1994). The use of isoelectric focusing and polyacrylamide gel electrophoresis of soluble proteins in the taxonomy of the genus Heterorhabditis (Nematoda: Heterorhabditidae).Nematologica 40, 601-612.

JUNG, K. (1991). Observations on the infective juveniles of the insect parasitic nematode, Heterorhabditis sp., at two storage temperatures. Mededelingen van de Faculteit der Landbouwwetenschappen RijksuniversiteitGent 56/3b, 13051312.

Koppenhöfer, A.M., Kaya, H.K. \& TAORmino, S.P. (1995). Infectivity of entomopathogenic nematodes (Rhabditida: Steinernematidae) at different soil depths and moistures. Journal of Invertebrate Pathology 65, 193-199.

Kung, S.-P., Gaugler, R. \& Kaya, H.K. (1991). Effects of soil temperature, moisture, and relative humidity on entomopathogenic nematode persistence. Journal of Invertebrate Pathology 57, 242-249.

Lewis, E.E. Selvan, S. Campbell, J.F. \& Gaugler, R. (1995). Changes in foraging behaviour during the infective stage of entomopathogenic nematodes. Parasitology 110 , 583-590.

MolyneuX, A.S. (1985). Survival of infective juveniles of Heterorhabditis spp., and Steinernema spp. (Nematoda: Rhabditida) at various temperatures and their subsequent infectivity for insects. Revue de Nématologie 8, 165-170.
MolyneuX, A.S. \& BedDing, R.A. (1984). Influence of soil texture and moisture on the infectivity of Heterorhabditis sp. D1 and Steinernema glaseri for larvae of the sheep blowfly, Lucilia cuprina. Nematologica 30, 358-365.

Patel, M., Stolinski, M. \& Wright, D.J. (1997). Neutral lipids and the assessment of infectivity in entomopathogenic nematodes: observations on four Steinernema species. Parasitology 114, 489-496.

QIU, L. \& BedDing, R. (2000). Energy metabolism and its relation to survival and infectivity of infective juveniles of Steinernema carpocapsae under aerobic conditions. Nemato$\log y$ 2, 551-559.

Smits, P.H., Groenen, J.T.M. \& De RAAy, G. (1991). Characterization of Heterorhabditis isolates using DNA restriction fragment length polymorphism. Revue de Nématologie $14,445-453$.

Stock, S.P., Griffin, C.T. \& Burnell, A.M. (2001). Morphological characterisation of Heterorhabditis isolates from the "Irish group" (Rhabditida, Heterorhabditidae), additional evidence supporting their recognition as a distinct species: Heterorhabditis downesi, n. sp. Systematic Parasitology, in press.

STOREY, R.M.J. (1984). The relationship between neutral lipid reserves and infectivity for hatched and dormant juveniles of Globodera spp. Annals of Applied Biology 104, 511-520.

Timper, P., KAYA, H.K. \& JAFFEe, B.A. (1991). Survival of entomogenous nematodes in soil infested with the nematodeparasitic fungus Hirsutella rhossiliensis (Deuteromycotina: Hyphomycetes). Biological Control 1, 42-50.

Van Gundy, S.D., Bird, A.F. \& Wallace, H.R. (1967). Aging and starvation in larvae of Meloidogyne javanica and Tylenchulus semipenetrans. Phytopathology 57, 559-571.

VÄNNINEN, I. (1990). Depletion of endogenous lipid reserves in Steinernema feltiae and Heterorhabditis bacteriophora and effect on infectivity. Proceedings of the Vth InternationalColloquium on Invertebrate Pathology, Adelaide, Australia, 2024 August 1990, Society for Invertebrate Pathology, p. 232. [Abstr.] 